\title{
PRINCIPLES OF STATE FINANCIAL CONTROL OF UKRAINE IN THE CONDITIONS OF EUROPEAN INTEGRATION
}

\author{
Yuliya Pustovit ${ }^{1}$, Viktor Timashov ${ }^{2}$, \\ Kyiv National University of Trade and Economics, Ukraine \\ Alina Berher ${ }^{3}$, \\ National University of Food Technologies, Ukraine
}

\begin{abstract}
The purpose of the study is an improvement of principles of state financial control of Ukraine taking into account European advanced experience. The subject of the research is a comparative analysis of financial control principles and principles of state financial control of Ukraine with the international principles of financial control, envisaged at the international level, and the establishment of the expediency of their implementation in the national legislation in connection with the terms of European integration. The methodological background of the research is the combination of theoretical and scientific methods: analysis, synthesis and comparison, theoretical and logical generalization. The theoretical approaches are analysed according to the determination of conceptcategory of terms: "principle of financial control," "principle of state financial control." Existed principles of financial control, principles of state financial control of Ukraine, leading principles of financial control, what determined in Lima Declarations of Guidance on Auditing Precepts, general principles of supreme bodies of financial control activity that are envisaged in Declaration about general principles of supreme bodies of financial control activity of states-participants of CIS are investigated. Carrying out the analysis of financial control principles, principles of state financial control of Ukraine, and international principles of financial control, we reached a conclusion that basic principles (principles of legality, independence, objectivity, impartiality, publicity, neutrality) are already normatively envisaged. There is the part of international principles (principle of competence, publicity, efficiency, well-proven, observance of professional ethics, violation prevention, obligatory of responsibility offensive for the accomplished violations of financial discipline) that doesn't have the normative consolidation in laws and regulations of Ukraine. International principles of financial control are partly marked in the scientific literature of Ukraine, but it not enough in order that they become leading ideas, the fundamental basis of the financial control system development of European standard in Ukraine. Conclusions. It is suggested to improve the statutory provision of state financial control: to manage further development of conceptual bases of the system of state financial control principles, their classification; in branch legislation, to specify principles of state financial control in accordance with their kinds; to complement the Law of Ukraine "On Basic Principles of State Financial Control Realization in Ukraine." The list of realization principles of state financial control in Ukraine that will become one of the meaningful steps on the way of European integration of Ukraine to the European Union is envisaged.
\end{abstract}

Key words: control, financial control, state financial control, principles of financial control, principles of state financial control.

\section{JEL Classification: G28, G29}

\section{Introduction}

The current economic relations development in Ukraine, the improvement of management processes requires scientific analysis of transformations, understanding and recognizing of the organizational and economic mechanisms used by the state during its core functions.

Significant violations of budget legislation and inefficient use of budget resources by the state authorities and bodies of local self-government, shadow economy,

\footnotetext{
Corresponding author:

${ }^{1}$ Department of Administrative, Financial and Information Law, Kyiv National University of Trade and Economics.

E-mail address: pustovitjuly@gmail.com

${ }^{2}$ Department of Administrative, Financial and Information Law, Kyiv National University of Trade and Economics.

E-mail address: timashovv@bigmir.net

${ }^{3}$ Department of Marketing, National University of Food Technologies.

E-mail address: alinaberger2016@gmail.com
} 
macroeconomic instability, poor business climate, low productivity and international competitiveness, lack of investments are priority problems that hinder the country's economic growth.

To overcome these problems, the Government of Ukraine should follow a Single Concept in its work. The initial step in the system work of the Government was the development and approval of the Government's Priority Action Plan for 2016, aimed at ensuring an increase in the standard of citizens life and, as a result, the sustainable economic development of society (Order of the Cabinet of Ministers of Ukraine, 2016).

Subsequently, Government's Priority Action Plan for 2017 was approved. The reform of the public finance management system has been initiated, which will help to prevent a crisis in the future. Ukraine's Cabinet of Ministers approved a public administration reform strategy for 2016-2020 and the plan of its implementation. The strategy envisages short-term and long-term tasks. The concept determines the field for reforming public administration and the key principles of the reform. The concept has been approved by the European Union (EU). The EU is ready to provide assistance to Ukraine in its implementation.

The document touches only the issues of operation of central executive power branch and local public administrations in part of civil service. It does not touch local self-government agencies. The strategy foresees the necessity of its regular revision, taking into account the results of its implementation.

Improving the well-being of citizens has become the main goal of the Government. The minimum wage has been increased by 16.1 percent since January 2016. From January 1,2017 , the minimum wage has been increased twice.

In the Medium-Term perspective to implement priority to reform and the creation of an efficient and high-quality system of public financial control activities planned, including the:

- carrying out tasks, defined in the Strategy for system reforming of public finance management for 2017-2020 years, approved by the Regulation of the Cabinet of Ministers of Ukraine on February 8, 2017 No. 142 on the public financial control and achieving results on tasks implementation;

- approving and implementation by the SAS of the Concept of the state policy realization in the sphere of system reforming of public financial control till 2021, which is on the development stage now;

- development of the legal framework and methodological support of the public financial audit by harmonization with international standards (the Institute of Internal Auditors (IIA), the International Federation of Accountants (IFAC), INTOSAI) and methodology, and EU best practice of audit in the sphere of public finances;

- modernization and improvement of the efficiency and effectiveness of activities of public financial control authorities, implementation of audit results and receiving of economic effect;

- introducing a mechanism of accountability of public authorities for the legality and effectiveness of their activities and decision making;

- clear division of functions and powers between the state financial control authorities;

- definition and normalization of a list and a mechanism of administrative services providing by the SAS for public and local authorities and economic agencies;

- improvement of information support of state financial control system by creating a common information and analytical base of the state financial control;

- strengthening of human resource capacity of state financial control authorities and an effective model of qualified personnel development and training in the sphere of the state financial control.

Achieving goals of the Medium-Term plan priorities for the Government until 2020 are the development of the system governance, which is able to launch systematic reforms in Ukraine with all democratic principles, the rule of law, protection of property rights and gender equality, inclusiveness and collaboration, is one of the base assumptions of success of Ukraine. The structure and the system of public administration work have to provide timely public services with the economical use of public resources and with the transparent and accountable way by citizens, saving of public services and welfare for people of ecological clean and the varied world around. The quality of public services indicates the level of respect of the State to the rights and dignity of every person.

The Government will ensure effective and transparent use of public finances and implements the budget planning for the medium term in the context of major spending agencies at the level of the state budget to improve the efficiency and quality of public services.

The Ukrainian Government continues to be committed to European values and takes the necessary steps to further ensure the integration of Ukraine into the European political, economic, and legal space.

Medium-Term planning of consistent and complex reforms, in particular, defined by the Action Program of the Cabinet of Ministers of Ukraine, the Strategy for Sustainable Development "Ukraine-2020", the Public Administration Reform Strategy for 2016-2020, the Association Agreement between Ukraine, on the one hand, and the European Union, the European Atomic Energy Community and their Member States, on the other hand, the Memorandum of Cooperation between Ukraine and the International Monetary Fund (IMF), the Coalition Agreement and the Legislative Reform Plan, is the basis of sustainable economic growth, the achievement of European standards of citizens' life.

Providing for the effective state financial control of public and local authorities' activity during the management 
and usage of budget resources, the state financial control targeting increasing the level of efficient, legal, targeted, rational, resulted usage and saving financial resources of the State, fixed and other assets, achieving the growth of budget funds economy by its executors and recipients, eliminating violations, drawbacks and preventing them in the process of its activity, increasing of managers responsibilities of the public sector for effective activity.

The state can function and develop properly only with a well-organized system of control over the production, distribution, and redistribution of the social product and other spheres of public life in the state.

In order to organize in the state a system of state financial control of the European model, it is necessary to make all transformations, starting with the principles, the basic fundamental provisions that will be the main benchmark for such changes.

Therefore, the subject of our study will be a comparative analysis of the principles of financial control and principles of the state financial control of Ukraine with the international principles of financial control, enshrined at the international level, their implementation in national legislation in connection with European integration.

\section{Analysis of recent research studies and publications}

Today scientists are interested in the problem of principles of state financial control. There is a significant number of scientific works, in which the concept, content of the principles of financial control as a type of activity is examined. Also in the Ukrainian scientific literature, the international experience of forming models of state financial control and the possibility of implementing these models in Ukraine are actively studied. Among such scientists are N. Barabash, V. Baranovska, A. Butko, L. Gutsalenko, M. Nykonovych, L. Savchenko, O. Orlyuk, M. Tulupova, O. Vasylyk, Yu. Voloshyn, L. Voronova, and others.

But despite this, in the legal literature, there is no comprehensive study devoted to this issue. The discovery and coverage of the principles of branches, sub-sectors, and institutes of law are hampered by the weak general theoretical development of the problem, but it must be said that the general theory of law is not able to independently study the basic principles of law without relying on the generalization of branch legal sciences.

\section{Presentation of the main material of the study}

\subsection{Theoretical and applied content of the} financial control

At the present stage of development of a market economy, the control function of finance has become particularly relevant, due to a certain specificity of this activity and allows actively influencing economic processes in the state.

An important part of the management system that guarantees quality and ensures an effective implementation of governmental activity is control.

The essence of the control is the implementation of purposeful influence on the objects of management, which provides for systematic supervision, monitoring their activities to detect deviations from the established norms, rules, requirements or tasks in the process of their implementation (Gutsalenko et al., 2017: 5-6).

Control as a type of relationship is the attitude of the subject to their own activities or the activities of other subjects in terms of a compliance with certain rules. Control may be state and public and be used in various structures, including nongovernmental ones.

Having considered the definition of control and its essence, let us turn to the definition of financial control since financial control is an integral part of the financial activity of the states. The state financial control has a special place in the system of the state control.

Financial control is a special sphere of state control related to the activities of financial institutions to detect violations of law, financial discipline and expediency in the formation, distribution, and use of state and municipal monetary funds (Voronova et al., 2009: 94).

Financial control is an element of the financial management system, a special sphere of cost control over the financial activities of all economic subjects (state, regions, enterprises, and organizations), compliance with financial and economic legislation, expediency costs, economic efficiency of financial and business operations (Vasylyk, 2000: 401).

Financial control is a complex and purposeful financial and legal activity of the financial control bodies or their subdivisions or representatives, as well as persons authorized to exercise control based on the provisions of the acts of the current legislation. It consists in establishing the actual state of affairs at the controlled object for its financial and economic activity and is aimed at ensuring legality, financial discipline, and rationality in the course of the formation, distribution, ownership, use, and alienation of assets for the purpose of effective social and economic development of all subjects of financial legal relations (Gutsalenko et al., 2017: 6).

Consequently, after considering these three definitions of financial control, we can conclude that during such a control the state interests are satisfied, which consist of the successful implementation of the state financial policy, the effective use of the financial resources of the state.

Financial control over its economic essence is a management function that includes a set of observations, inspections on the management object activity in order to assess the reasonableness and efficiency of decision-making and results of their implementation. In general, financial control is a universal phenomenon. 
Its universality is its use in various spheres of social life, namely: scientific, political, social, economic, etc. The essence of financial control is disclosed through the relationship between the use and operation of finance. Financial control is applied there and when the finances are operating. Finance is a collection of forms and methods for the formation, distribution, and use of centralized and decentralized funds in order to fulfil functions and tasks of the state, enterprises, and people to ensure conditions for expanded reproduction, meeting the social and other needs of society (Vasylyk, 2000: 402).

The effectiveness of the work of executive authorities and local self-government in the state depends on the control over the implementation of laws, decisions, orders, and the proper organization of their implementation. Systemic and comprehensive control contributes to ensuring the scientific validity of decisions, regulations, and other statutory documents, their timely implementation. It is a prerequisite for the detection and elimination of defects in the objects of management activities and the reasons that give rise to them. Control disciplines employees of the management apparatus, makes it possible to objectively assess the level of their competence and compliance, promotes the spread of the positive practice of the work (Gutsalenko et al., 2017: 5).

Legal science and current legislation contain a number of fundamental principles for the implementation of financial control. The observance of these principles allows the financial control bodies to fully exercise their powers. We will start analysing the principles of financial control starting from generic principles that have become the foundation (basis) for implementing these principles in general.

State financial control is a kind of financial control carried out by the relevant state financial control bodies. It consists in establishing the actual state of affairs in observance of requirements of the current legislation at the controlled object, aimed at ensuring the legality, financial discipline, and rationality during the formation, distribution, possession, use, and alienation of assets owned by the state, as well as the use of funds that remaining in the subject of financial legal relations in connection with granted privileges for payments to the budgets, state extra-budgetary funds and loans received under the guarantees of the Cabinet of Ministers of Ukraine (Gutsalenko et al., 2017: 6).

The development of modern state financial control is based on a hierarchically structured system of principles. Principles of state financial control are the basic, fundamental ideas of regulation of financial and legal relations in the implementation of state financial control sphere and ensure the unity of the normative content of this section of financial law, on the one hand, they are the factors determining the directions of its internal development, and on the other hand, they are the tools to overcome various contradictions and collisions.

\subsection{Principles of financial control in Ukraine}

There are three main forms of financial control: preventive control, operational control, retrospective control. Operational control is performed during the financial and economic operations, retrospective control - respectively after the reporting period. But the most important one is preventive control, which is performed until financial transactions. The assessment of the validity of programs and financial forecasts, financial plans based on the analysis of macroeconomic indicators of the state economy are carried out. It is performed to prevent the violation of laws, rational use of financial resources.

According to the Law of Ukraine "On Basic Principles of Implementation of State Financial Control in Ukraine," the main tasks of body of the state financial control are: implementation of the state financial control of use and safety of the state financial resources, non-current and other assets, correctness of determination of need for budgetary funds and capture of obligations, effective use of means and property, condition and reliability of financial accounting and the financial reporting in the ministries and other executive bodies, the state funds, funds of obligatory national social insurance, budgetary institutions and subjects of managing of public sector of economy, and also at the companies, in organizations and the organizations, which receive (received in the period which is checked) means from budgets of all levels, the state funds and funds of obligatory national social insurance or use (used in the period which is checked) the state-owned or municipal property (further - under control organizations), behind observance of the budget legislation, compliance with law about public procurements, activities of business entities irrespective of pattern of ownership, which are not carried by the legislation under control organizations, by a court decision, accepted in criminal proceedings.

State financial control is provided with a body of the state financial control through carrying out the state financial audit, check of public procurements, and inspection.

The procedure for carrying out by the body of the state financial control of the state financial audit, inspection, and checks of public procurements is established by the Cabinet of Ministers of Ukraine (Law of Ukraine ).

According to Article 3 of this Law of Ukraine, the state financial audit is a kind of the state financial control and consists in check and the analysis by body of the state financial control of actual state of cases of rather legal and effective use of the public or municipal funds and property, other assets of the state, correctness of conducting financial accounting and reliability of the financial reporting, functioning of internal control system. Results of the state financial audit and their assessment are stated in the report.

In the opinion of V. Baranovska, the main directions of state financial control are the social relations that 
arise, change, and cease in the public financial activity sphere, namely:

- verification of performance of functions of accumulation, distribution, and use of financial resources by state authorities and local self-government in accordance with their competence;

- verification of fulfilment of financial obligations to the state and local self-government bodies, organizations, and citizens;

- checking the correct use of state and municipal enterprises, institutions, organizations of monetary resources, which are in economic management or operational management (budget and own funds, bank loans, extra-budgetary and other funds);

- verification of compliance with rules of financial transactions, calculations and storage of funds by enterprises, organizations, institutions;

- identification of internal reserves of production opportunities for improving the profitability of the economy, the growth of labour productivity, more efficient use of material and money resources;

- elimination and prevention of violations of financial discipline. In case of their detection in the established procedure, the measures of action against organizations, officials, and citizens are used; the compensation for material damage to the state, organizations, citizens is provided (Baranovska, 2012: 65).

In the process of state financial control, the bodies that carry it out must be guided by the basic principles. In particular, the principles reflect the legality of social development, the needs of this society. This is their social conditionality, dependence on real-life conditions. The study of the system of state financial control principles, as well as their use in law enforcement practice, is a prerequisite for building an effective system of financial control.

The study of the principles of state financial control we begin with the fundamental category of "principles of law." This category is one of the main in the theory of law. Principles of law are also important for the study of branch legal sciences, including financial and legal.

First of all, in the context of this problem, we should pay attention to the general concept of the principle of law in order to formulate the concept of principles of state financial control.

The term "principle" is defined as the basic principles, original ideas characterized by universality, general significance, higher imperative, and reflect the essential provisions of theory, doctrine, science, systems of domestic and international law, political, state or public organization. These principles have a property of abstract reflection of the social activity laws, which determines their special role in the structure of many phenomena (Voloshyn, 2003: 110-111).

M. Tulupova determines the principle of law as an abstract expression of the meaning of some legal norms existing in the form of an idea and expressed in the form of a rule of law, which allows the separation of legal norms from those that conflict with the law. So, we can determine the principles of the state financial control implementation (Tulupova, 2007: 49).

The principle of state financial control is the fundamental and guiding ideas expressed in the form of legal provisions that determine the content of the regulation of state financial control, in many cases, serve as the highest criterion for the legality of the behaviour of participants in legal relations in the field of public financial control, legal rules of state financial control.

The principles that are the basis of state financial control can be defined as theoretically substantiated and normatively fixed principles of the very beginning of the essence of state financial control. These principles are its main content, determine the general direction of legal regulation of the state and municipal entities in the state financial control sphere and direct activities to achieve its goals and objectives.

The principles of state financial control are not isolated from each other; they are integrated into the system.

As can be seen from the above (the formal certainty), we can identify: the principles enshrined directly in the rules of law (e.g. the principle of independence of control); the principles arising from the content of legal norms, but directly to them is not fixed (e.g. the principle of the unity of the purpose and objectives of the financial control) (Butynets, 2000: 97).

On the nature of legal relations falling within the scope of the principle, the financial control principles can be divided into legal ("regulatory", e.g. the implementation procedure of the financial control, namely: legality, transparency, independence, etc.), "economic" (an economic component in their content, e.g. the principle of budget efficiency, the principle of the financial importance of the object of control taking into account economic indicators in the control), and "organizational and methodical" (determine the organization and activities of the financial control subjects).

In addition, depending on the ways of external expression of the principles in those or other formal legal sources the principles can be enshrined in international legal acts and treaties, the Constitutions, legislation, regulations (Butko \& Marchenko, 2013: 129-130).

State financial control as an integral part of the financial activity has the same principles of its implementation: legality, transparency, planning, as well as relevant specific principles: independence of control, objectivity, and competence, etc. (Butko \& Marchenko, 2013: 130-134).

According to the sphere of action, the legal principles are divided into the principles that are inherent: in law in general (general law); in a group of related sectors (intersectoral); separate branches or institutes of law (Semenov, 1982: 28).

So, the principles of state financial control of Ukraine are classified according to the following criteria: 
- the legislative consolidation - the legal and doctrinal principles;

- the nature of legal relations - legal, economic and organizational and methodical principles;

- depending on the ways of external expression, the principles may be enshrined in international legal acts and treaties, the Constitution, legislation, by-laws;

- in the sphere of action - general law, intersectoral, sectoral principles.

It is worth noting that in legal opinion, there are different approaches to the classification of the principles of law, their conjunction with those or other social phenomena but, as a rule, in one issue there is unity of opinions - legal principles are interpreted as "thoughtstarter", "outgoing", "governing" ideas underlying the law.

As a part of this study, we must consider the question: "What is the system of principles inherent in state financial control and their role in regulating relations in this area?"

Scientists make some attempts to formulate the system of financial control principles, but at present, there is no consistent approach to the definition of the system of financial control principles.

From the point of view of O. Orlyuk, the fundamental principles of financial control are:

- legality, objectivity, pooling of state, regional and private interests;

- distribution of control powers, in particular, sharing of powers of initiation and implementation of financial control between subjects;

- fullness of detail of the object by the control, which is achieved through continuous tracking or selective verification of certain segments of controlled objects;

- the authenticity of information that ensures its compliance with the actual financial resources, processes and results of the activity, which reflects this information;

- balance of control actions provides for the coherence of their internal and external orientation and ensures a balance of financial control;

- preventive control actions, aid in the timely implementation of controls to prevent significant deviations of the financial process from the norms;

- self-sufficiency of the control system, i.e. such elements of the control system, which ensures the efficiency of its operation and development;

- efficiency, i.e. adaptability of the control system to the financial activity of economic entities, which depends on the completeness of the implementation by the controlling entities of such basic requirements:

- control should be constant, regular, and systematic;

- to be timely in terms of implementation, qualitative and complete in relation to its objects;

- to be operating, effective, public and different;

- the principle of responsibility, i.e. the responsibility of control subjects for the effectiveness of the functioning of the financial control system and economic entities for the effects of control actions (Orlyuk, 2010:149-150).

In the opinion of O. Vasylyk, the principles of financial control include:

- independence of financial control as an integral attribute of democracy and a mandatory element of financial resources management;

- legislative consolidation of the independence of financial control bodies;

- determination of the necessity of the preliminary control and control over actual results;

- internal and external control as an obligatory condition of financial control;

- transparency of controlling bodies with the obligatory requirement of observance of commercial and other secrets protected by law (Vasylyk, 2000: 343).

L. Savchenko offers such a list of principles of financial control: the principle of legality, planning principle, objectivity concept, independence principle, transparency principle, the principle of competency, operational principle. The principles of publicity and transparency principle are distinguished by the author. The transparency is the compulsory passing of the financial documents, conclusions about the activities of the relevant control bodies through the representative bodies, the principle of publicity is defined as the promulgation of results of the activities of financial control bodies to the public (Savchenko, 2002: 13).

Having considered the principles of financial control, let us examine the principles of state financial control. State financial control is a type of financial control, so they have common principles.

L. Gutsalenko and his co-authors examine such principles of state financial control: principles of management and principles of implementation.

Principles of management of state financial control are:

- delimitation of the place, role, tasks, and functions of the bodies of state financial control in accordance with the competence of the legislative and executive power according to the Constitution and legislation of Ukraine;

- functional, organizational, personal, and financial independence of state financial control bodies and their officials from controlled objects;

- coordination of activities of state financial control bodies by way of eliminating duplication in their work and ensuring a single system of state financial control at all levels of government.

The main principles of the implementation of state financial control are: law, liability, strategic orientation, impartiality, comprehensiveness, systematicity, planning, regularity (timeliness), concreteness, profitability, transparency (under observance of official, commercial and other secrets protected by law), efficiency (Gutsalenko et al., 2017: 9].

In view of the foregoing, we can draw a conclusion 
that each element of state financial control has its own drawbacks and is far from being perfect. State financial control system exists as a combination of separated units and does not operate as a united system. State financial control system does not meet European requirements for a number of reasons, such as the prevalence of follow-up control over the previous and current. State financial control system is not based on thorough theoretical foundation. Most of the key concepts are even enshrined in law that hinders the development of such control and creates difficulties for furthers reforms. The current direction of Ukraine's development is aimed at strengthening the state's role in state financial management and reducing the overuse in the public sector. The system of state financial control, obviously, has a very strong structure, but the leading role is held by the State Financial Inspection of Ukraine, which controls the legitimacy, effectiveness, and proper use of public resources, and accuracy of accounting records and the reliability of financial reporting spending units.

\subsection{Comparative analysis of the principles} of financial control of Ukraine and the guidelines of financial control of the European Union

Having considered the principles of financial control and the principles of state financial control, we consider examining the financial control guidelines of the Lima Declaration of Guidelines on Auditing Precepts. Lima Declaration was the first INTOSAI document to comprehensively set out the importance of SAIs' independence. It reminded INTOSAI members that SAIs can only be objective and effective if they are independent from the audited entity and are protected from outside influence.

The International Organization of Supreme Audit Institutions (INTOSAI) is a professional organization providing an institutionalized forum for the SAIs from around the world to promote development and knowledge transfer, to discuss specific issues of mutual interest, to increase the added-value of the audits, to disseminate the latest developments in auditing and other applicable professional standards and best practices. INTOSAI recognizes that its strength lies in cooperation, experiences, special capacities and knowledge deriving from the cultural, social, economic, and governmental diversity of its global membership. At present, INTOSAI has 194 Full Members, 5 Associate Members and 1 Affiliate Member (The Lima Declaration, 1977 ].

Meeting in the United Arab Emirates in December 2016 at its Congress (XXII INCOSAI), the International Organisation of Supreme Audit Institutions (INTOSAI) agreed the Abu Dhabi Declaration. The XXII INCOSAI builds on INTOSAI's past achievements and initiatives, which aim at enabling SAIs to help their respective governments to improve performance, enhance transparency, ensure accountability and fight corruption. The declaration sets out the key outcomes of the Congress and how they will guide INTOSAI in the years to come.

The Abu Dhabi Declaration was developed within the following context:

Firstly, INTOSAI's comprehensive strategic planning process, which resulted in a new strategic plan for 2017-2022, aiming to increase the contribution SAIs make to improving accountability and transparency in public management around the globe;

Secondly, INTOSAI's revision of the statutes to align them more closely with the current structure, strategy, and objectives in order to help it better meet the needs of its members and stakeholders;

Thirdly, the endorsement by the UN of the 17 Sustainable Development Goals (SDGs) at the heart of the 2030 Agenda for Sustainable Development, which are in forces the need and demand for effective public audit and scrutiny and the action already taken by INTOSAI entities relating to auditing the implementation of the SDGs;

Fourthly, the establishment by the Knowledge Sharing Committee of a Community Portal to facilitate the sharing of knowledge; and

Finally, the adoption by INTOSAI of the new framework for professional pronouncements as a part of the ongoing efforts to improve INTOSAI's standards and standard-setting process, as well as all the ISSAIs and other INTOSAI professional pronouncements endorsed to date.

Founding principles of Public Sector Auditing refer to the following:

- purpose and types of audits;

- independence of SAIs and its members;

- relationship to Parliament, government, and administration;

- powers of SAIs;

- audit methods, audit staff, international exchange of experiences;

- reporting;

- audit powers of SAIs (The Abu Dhabi Declaration, 2016 ).

The declaration contains a comprehensive list of all goals and issues relating to government auditing, while simultaneously remaining remarkably significant and concise, making it easy to use with its clear language ensuring that focus does not wander away from the main elements.

The chief aim is to call for independent government auditing. A Supreme Audit Institution, which cannot live up to this demand, does not come up to standard.

Rule of law and democracy are essential premises for really independent government auditing and are the pillars, on which the Declaration of Lima is founded.

The precepts contained in the Declaration are timeless and essential values, which have maintained their topicality since the years they were first adopted. 
To sum up, the declaration points out basics for audits and audit institutions, which are necessary for achieving independent and objective results.

The success of the Lima Declaration is above all due to the fact that it contains a comprehensive list of all goals and issues relating to government auditing, while simultaneously remaining remarkably significant and concise, making it easy to use, with its clear language ensuring that focus does not wander away from the main elements.

The chief aim of the Lima Declaration is to call for independent government auditing. The Supreme Audit Institution, which cannot live up to this demand, does not come up to standard. It is not surprising, therefore, that the issue of the independence of Supreme Audit Institutions continues to be a theme repeatedly discussed within the INTOSAI community. However, the demands of the Lima Declaration are not satisfied by SAI just achieving independence; this independence is also required to be anchored in the legislation. For this, however, well-functioning institutions of legal security must exist, and these are only to be found in a democracy based on the rule of law. Rule of law and democracy are, therefore, essential premises for really independent government auditing and are the pillars, on which the Declaration of Lima is founded.

The traditional task of Supreme Audit Institutions is to audit the legality and regularity of financial management and of accounting.

In addition to this type of audit, which retains its significance, there is another equally important type of audit - performance audit, which is oriented towards examining the performance, economy, efficiency and effectiveness of public administration. Performance audit covers not only specific financial operations but the full range of government activity including both organisational and administrative systems.

The Supreme Audit Institution's audit objectives legality, regularity, economy, efficiency and effectiveness of financial management - basically are of equal importance. However, it is for each Supreme Audit Institution to determine its priorities on a case-by-case basis (The Lima Declaration, 1977 ).

Considering the principles of state financial control some authors hanker that: "Appeal to experience the world community has developed the main principles of state financial control, the realization of which every modern civilized hanker. These principles are in the Lima Declaration (Supreme Audit Institutions): objectivity principle, independence principle, the principle of competency and principle of publicity" (Barabash \& Nykonovych, 2015: 46).

The next document, which establishes the general principles of activities of the Supreme bodies of financial control, is the Declaration on the general principles of activities of the Supreme Audit Institutions of the
Member States of the Commonwealth of Independent States (Declaration, 2001 ).

According to the Declaration on the general principles of activities of the Supreme Audit Institutions of the Member States of the Commonwealth of Independent States, the activities of the supreme bodies of financial control are based on the following principles: principle of legality, independence principle, objectivity principle, principle of competency, operational principle, evidence-based approach, transparency principle, professional ethics principle.

It is worth noting that five principles of the Lima Declaration and five controlling principles of the Declaration on the general principles of activities of the Supreme Audit Institutions of the Member States of the Commonwealth of Independent States are the same principles, they are: principle of legality, independence principle, objectivity principle, principle of competency, transparency principle. All other principles are different.

The guidelines for financial control of the Lima Declaration (principle of publicity, principle of efficiency, principle of preventing violations, principle of compulsory liability for committing a violation of financial discipline) are not enshrined in the Declaration on the general principles of activities of the Supreme Audit Institutions of the Member States of the Commonwealth of Independent States. But in the Declaration on the general principles of activities of the Supreme Audit Institutions of the Member States of the Commonwealth of Independent States, there are several distinctive principles: operational principle, evidencebased approach, professional ethics principle.

Above analysis of these principles, we can examine and compare the Lima Declaration principles and the principles of Declaration on the general principles of activities of the Supreme Audit Institutions of the Member States of the Commonwealth of Independent States with the principles of financial control in Ukraine in general and also the principles of state financial control: principle of legality, independence principle, objectivity principle, principle of efficiency, evidencebased approach, principle of competency, principle of publicity, professional ethics principle, operational principle, transparency principle, principle of preventing violations, principle of compulsory liability for committing a violation of financial discipline.

So we have examined the Lima Declaration principles and the principles of Declaration on the general principles of activities of the Supreme Audit Institutions of the Member States of the Commonwealth of Independent States.

Let us start our comparative analysis of the principles that $\mathrm{O}$. Orlyuk determined as the fundamental principles of financial control. Among these principles, only four international principles are in the author's list: the principle of legality, objectivity principle, the principle of efficiency, the principle of responsibility. 
Among the principles of financial control, which were defined by V. Vasylyk, there are two international principles of financial control - independence principle and transparency principle.

L. Savchenko among the principles of financial control determines the following international principles: the principle of legality, objectivity principle, independence principle, the principle of efficiency, the principle of publicity, and transparency principle.

L. Gutsalenko and his co-authors determine such three principles of state financial control: principle of legality, sure thing principle, and transparency principle.

In view of the foregoing, we can conclude that the Lima Declaration principle of preventing violations and principle of efficiency, evidence-based approach, professional ethics principle, which are enshrined in the Declaration on the general principles of the activities of the Supreme Audit Institutions of the Member States of the Commonwealth of Independent States, are not among the principles of financial control determined by these scientists.

The competence of financial control bodies, e.g. the Accounting Chamber, the State Audit Service of Ukraine, the State Fiscal Service of Ukraine and others, is detection of violations of financial discipline, measures for the prevention of violations in the financial sphere, so the principles of their activities have to be coordinated with the Lima Declaration principles and the principles, which are enshrined in the Declaration on the general principles of the activities of the Supreme Audit Institutions of the Member States of the Commonwealth of Independent States.

It is worth examining in more detail the competence of financial control bodies. Article 3 of the Law of Ukraine "On Accounting Chamber" No. 576-VIII dated 02 July 2015 regulates the principles of the Accounting Chamber activities and the guarantees of its independence: the principles of legality, independence, objectivity, fairness, publicity, and political impartiality. The independence of the Accounting Chamber is provided by: 1) established by the Constitution of Ukraine and this Law order of appointment and dismissal of members of the Accounting Chamber; 2) determined by this Law and other laws of Ukraine guarantees of the Accounting Chamber activities; 3) special order organizational support of the Accounting Chamber activities established by law. The Accounting Chamber in the exercise of its authority is independent of any improper influence, pressure or interference. Unlawful interference with the exercise by the Accounting Chamber of powers granted by law is prohibited and shall entail liability established by the law. The Accounting Chamber uses in its work the basic principles of the International Organization of Supreme Audit Institutions (INTOSAI), the European Organization of Supreme Audit Institutions (EUROSAI), and International Standards of Supreme
Audit Institutions (ISSAI) to the extent that is not contrary to the Constitution and the laws of Ukraine (Law of Ukraine, 2015 ).

Having made a comparative analysis of the international financial control principles with the principles of financial control of Ukraine, which are directly enshrined in the national legislation, we have established that the Law of Ukraine "On Accounting Chamber", with the amendments and additions, establishes four main international principles (the principles of legality, independence, objectivity). As for the principles of fairness, publicity, they are not fixed at the international level, they are purely Ukrainian property.

An analysis of the Regulations "On State Audit Service of Ukraine" (the Resolution of the Cabinet of Ministers of Ukraine, 2016 ), "On State Fiscal Service of Ukraine" (the Resolution of the Cabinet of Ministers of Ukraine, 2016 ), and the Law of Ukraine "On Basic Principles of Implementation of State Financial Control in Ukraine" (with the amendments and additions) (the Law of Ukraine, 1993 ) made it possible to conclude that none of these laws and regulations directly consolidate principles of financial control.

\section{Conclusion}

The analysis shows the need to improve a state financial control. A lot of problems should be solved but, according to the results of state financial control practice during the last years, it has lost its effectiveness. For improving the current state financial control system, the specialists have taken a series of statutory documents. The most important judicial issue is to provide the Accounting Chamber of Ukraine to represent the State in legal proceedings and to fulfil the preventive functions. In the developed countries, financial control is a part of the state regulation in order to detect deviations from the regulations and violations of the principles of legality and efficiency.

So, the subjects of state financial control include a lot of regulatory authorities. It should be noted that there is a significant intersection of their functions. The indicated problem has been realized by a majority of lawmakers, but yet not completely eliminated. At present, all subjects of state financial control have almost identical powers, which are purely external.

The objects of state financial control are public and municipal services. Nowadays state financial control methods used in the practice of regulatory authorities are totally agreed with the key purpose of control measures - identifying violations and punishment of persons committed them. The main drawback of current state financial control methods is their inability to find reserves of their activity and make provisions for preventing offenses. Therefore, it is necessary to review the existing methods and improve them according to current requirements. 
The state financial control forms reflect the expression of a particular subject of state financial control. Nowadays the main form is a revision. The basis for stare internal financial control, performed by SFI, along with different types of control is an inspection. Such a type of control over the activities of public and municipal sectors is aimed primarily at detecting violations and punishing responsible persons but not assessing the results, achieved in public finance management. The current need to perform the inspection is due to an extremely low level of financial discipline in the public sector, the lack of internal control system, and decentralized internal audit in the public sector.

The classification of state financial control is sufficiently completed but also has many disadvantages. This is especially true for follow-up control over the previous and the current one, which is rather ineffective according to the opinion of the international community.

In Ukraine, the Accounting Chamber performs the state financial control function in a part of the monitoring of using the State Budget of Ukraine and Government financial inspection of Ukraine within its powers defined by law.

An important sign of readiness to join the EU is to establish procedures for the compensation for loss of finance. But today, Ukrainian legislation does not provide an effective mechanism for the compensation of lost budget funds and the responsibility of officials for violations of financial discipline. Experience in other countries shows that to deal with cases of abuse by tax officials of their rights, there is a widespread practice of recovery of costs and expenses from the tax authority. The results of state financial control and audit must be based on the application of common procedures and methods, and also on sufficient evidence, which enable a state inspector or a public accountant to express logical and competent opinions.

In view of the above, it is necessary:

- to further develop conceptual foundations of the system of principles of state financial control, their classification;

- in sectoral legislation, specify the principles of state financial control according to their types;

- to amend the Law of Ukraine "On Basic Principles of Implementation of State Financial Control in Ukraine" by the article, which provide a list of principles for the implementation of state financial control in Ukraine (legality, independence, objectivity, efficiency, accountability, competence, professional ethics, transparency, publicity, prevention of violation, obligatory liability for violations of financial discipline), which will become an important step towards the European integration of Ukraine into the European Union.

\section{References:}

Barabash, N. \& Nykonovych M. (2015) Udoskonalennia systemy derzhavnoho finansovoho kontroliu [Improvement of the system of state financial control]. Financial control (No. 3 (26)), P. 44-47.

Baranovska, V. (2012) Derzhavnyi finansovyi kontrol v Ukraini: problemy ta shliakhy yikh vyrishennia [State financial control in Ukraine: problems and ways of their solution]. Analysis, control and analysis in the management of entrepreneurial activity (Cherkasy), P. 62-64.

Butko, A. \& Marchenko, B. (2013) Vnutrishnii finansovyi kontroliu u systemi finansovoho kontroliu derzhavy [Domestic financial control in the system of financial control of the state]. Finance of Ukraine. P. 127-136.

Butynets, F. \& Bardash, S. (2000) Kontrol ta reviziia [Control and Revision] (Zhytomyr: ZhITI), 512 p.

Declaration on general principles of activity of the highest financial control bodies of the member states of the Commonwealth of Independent States (2001). The Verkhovna Rada of Ukraine (dated June 8), available at: http://zakon0.rada.gov.ua/laws/show/997 a40

Gutsalenko, L. Derii, V., \& Kotsupatry, M. (2017) Derzhavnyi finansovyi kontrol [State financial control] (Kyiv: Tsentr uchbovoi literatury), $424 \mathrm{p}$.

Law of Ukraine (1993) Pro osnovni zasady zdiisnennia derzhavnoho finansovoho kontroliu v Ukraini [On the Basic Principles of Implementation of State Financial Control in Ukraine] (dated January 26, No. 2939-XII). The Verkhovna Rada of Ukraine, available at: http://zakon2.rada.gov.ua/laws/show/2939-12

Law of Ukraine (2015) Pro Rakhunkovu palatu [On Accounting Chamber] (dated July 2 No. 576-VIII). The Verkhovna Rada of Ukraine, available at: http://zakon2.rada.gov.ua/laws/show/576-19

Order of the Cabinet of Ministers of Ukraine (2016) Pro zatverdzhennia planu priorytetnykh dii Uriadu na 2016 rik [On Approval of the Plan of Government Priority Actions for 2016] (dated May 27, No. 418-p).

Orlyuk, O. (2010) Finansove pravo. Akademichnyi kurs [Financial law. Academic course] (Kyiv: Yurinkom Inter), 808 p.

Savchenko, L. (2002) Pravovi problemy finansovoho kontroliu v Ukraini [Legal problems of financial control in Ukraine] (Kharkiv), 42 p.

Semenov, V. (1982) Konstitutsionnyie printsipyi grazhdanskogo sudoproizvodstva [Constitutional Principles of Civil Proceedings] (Moscow).

The Abu Dhabi Declaration XXII INCOSAI (2016). United Arab Emirates. International Organization of Supreme Audit Institutions, available at: http://www.intosai.org/events/congresses-incosai/congress-themes-finaldocuments.html\#c4202 
The Law of Ukraine (1993) About the basic principles of implementation of the state financial control in Ukraine (with the amendments and additions) (dated January 26, No. 2939-XII), available at: http://cis-legislation.com/ document.fwx?rgn=14460 (the last edition from December 23, 2015).

The Lima Declaration of Guidelines on Auditing Precepts (1977). INTOSAI. International Organization of Supreme Audit Institutions, available at: http://www.intosai.org/issai-executive-summaries/view/article/issai-1the-lima-declaration.html

The Resolution of the Cabinet of Ministers of Ukraine (2014) Polozhennia pro Derzhavnu fiskalnu sluzhbu Ukrainy [The Provision On the State Fiscal Service of Ukraine] (dated May 21, No. 236). Verkhovna Rada of Ukraine, available at: http://zakon3.rada.gov.ua/laws/show/236-2014-\%D0\%BF

The Resolution of the Cabinet of Ministers of Ukraine (2016) Polozhennia pro Derzhavnu audytorsku sluzhbu Ukrainy [The Provision On the State Audit Office of Ukraine] (dated February 3, No. 43). Verkhovna Rada of Ukraine, available at: http://zakon2.rada.gov.ua/laws/show/43-2016-\%D0\%BF

Tulupova, M. (2007) Publichnyie finansyi Rossiyskoy Federatsii: novyie podhodyi k pravovomu regulirovaniyu [Public Finances of the Russian Federation: New Approaches to Legal Regulation]. Center for Public Legal Research (ed. Kozyrina, A.) (Moscow: TsPPI), 177 p.

Vasylyk, O. (2000) Teoriia finansiv [Theory of Finance] (Kyiv: NIOS), 416 p.

Verkhovna Rada of Ukraine (2017) Serednostrokovyi plan priorytetnykh dii Uriadu do 2020 roku [Medium-Term Plan of Priority Actions of the Government by 2020], available at: http://zakon2.rada.gov.ua/laws/show/2752017-\%D1\%80

Voloshyn, Yu. (2003) Pryntsyp [Principle]. Legal Encyclopedia, volume 5 (Kyiv: Ukrainska entsyklopediia), 736 p. Voronova, L., Kucheriavenko, M., Prishva, N. at al. (2009) Finansove pravo Ukrainy [Financial Law of Ukraine] (Kyiv: Pravova yednist), 395 p. 